Reprinted from ScIENCE, January 30, 1953, Vol. 117, No. 3031, page 114.

\section{University of Michigan Geological Field Work in Mexico}

A PROGRam of studies of sections across the Mexican geosyncline at right angles to the marginal land masses has been designed to determine lateral variations in structure, lithology, and faunal relationships of successive geologic formations. Although purely scientific, these regional studies have economic implications. Their bearing on ore deposition is threefold: (1) to provide the regional setting for detailed studies of structure in the mines and mining districts along the eastern edge of the Sierra Madre Occidental; (2) to place the age of the prelava sedimentary rocks on a sound regional and paleontologic basis; (3) to locate intrusive bodies with respect to mineralization. Petroleum exploration may be guided by the interpretation of geologic history resulting from the series of stratigraphic sections measured in mountain ranges of the Plateau Central. The sequence of faunas and faunal zones recognized in each formation provides useful markers, which should be found in wells penetrating the subsurface. Structural features mapped in the mountain ranges can be projected into the basins, where geologic conditions may be obscure.

Field work in northern Mexico in the area of the early Mesozoic "Coahuila Peninsula" was resumed during July and August 1952 by a party from the Museum of Paleontology of the University of Michigan. Lewis B. Kellum, in charge of the program, was accompanied by two graduate students, Bob F. Perkins, of Dallas, Tex., and Cecil C. Kersting, of Muskegon, Mich. The primary purpose of the investigation was to study the fauna of the Lower Cretaceous Aurora limestone and the geologic rela- tionships of the Aurora limestone to the Cuchillo evaporites.

The area mapped is along the Durango-Coahuila state line in the central part of the Sierra de Tlahualilo, about 250 miles south of the international border at the Big Bend of the Rio Grande. The general structure of the Sierra de Tlahualilo in Cretaceous strata is a broad, northward-trending anticline. On this major structure is superimposed a variety of welldefined local deformations. A small area of voleanic rocks encroaches on the western side of the range.

Three stratigraphic sections were measured. Small patches of fossiliferous platy limestones and yellow marls of the Indidura formation were found beneath the volcanies resting on the Aurora limestone. Fossils were collected at four horizons in the Aurora, the lowest of which occurs in a silicified zone that may mark the top of the Cuchillo formation. The limestones below this zone weather darker gray, are interbedded with gypsum, and grade downward into the highly gypsiferous beds of the Cuchillo formation. Rudistids occur at the top of the Aurora limestone but are not the dominant element in the molluscan fauna. A faunal zone about $600 \mathrm{ft}$ below the top is characterized by a large assemblage of pelecypods, gastropods, brachiopods, and echinoids, of which Gryphaea marcoui Hill is the most abundant form. This zone, present throughout the area mapped, proved to be a most reliable datum plane in a thick limestone section. A few feet above this zone nautiloid cephalopods were found at several localities. The faunas from the Aurora will be studied in the $M \mathrm{M}$ seum of Paleontology during the coming year.

Lewis B. Kellum

Muscum of Paleontology, University of Michigan 